\title{
Preface to Special Issue on Performance and Translation
}

The previous issue (Fall 2019) of Delos began with a preface about prefaces, and so I will briefly harken back to that meta-literary move by beginning this preface with a quote from a preface.

In his famous introduction to what was to become his most infamous drama, The Playboy of the Western World (1907), Irish dramatist John Millington Synge observed: "In a good play every speech should be as fully flavoured as a nut or apple." Synge had lived among the denizens of Ireland's rugged western coast and turned their vernacular into poetry, and he was scornful of what he saw as the "pallid" language of realists like Ibsen, Strindberg, or Chekhov. To my knowledge, Synge (whose own dialogue was sometimes derided as "Synge-song") knew no Norwegian, Swedish, or Russian, so what he found "joyless" in the drama of his foreign peers was likely the result of inferior translation. Perhaps the crisp lucidity of Ibsen's Norwegian, the feverish vitality of Strindberg's Swedish, and the floating melancholy of Chekhov's Russian had trickled away by the time it made it to Synge's critical ear.

In this special issue of Delos, the contributors focus on translation and performance, translation for performance. The stage and its performers depend on the liveness and liveliness of language. Among translators of plays, there is a rule of thumb, though perhaps more honored in the breach than the observance, that the shelf-life of a theatrical translation is only about twenty-five years. In a quarter-century spoken language, as a living, shifting thing, mutates enough that what seemed fresh and colloquial then has become staid and dated now.

The example of Shakespeare is instructive. In the global English-speaking theatre his plays are of course performed, more or less, as he wrote them over 400 years ago. But in Germany, which since Wieland and Goethe in the eighteenth century embraced Shakespeare as if he were a native playwright who inconveniently happened to be writing in a foreign tongue, the question of which translation to use is a continually pressing one. The magisterial Schlegel-Tieck-Baudissin translations of the Romantic era were long the gold standard - it was in their words that Hamlet ruminated on Sein oder

Delos Vol. 35, No. 1, pp. v-vii. Copyright (C) 2020 University of Florida Press. doi: $10.5744 /$ delos.2020.1010 
Nichtsein - but the twentieth century increasingly demanded that Shakespeare answer to the urgencies of modernism, that he become less elevated and more streamlined, psychological, absurdist, political. Or rather that that which was already political, absurdist, etc. in his work be excavated and brought forth. As recently as 2017 Frank Günther completed a new German translation of all 37 plays. So while in England and the U.S. contemporary audiences are increasingly daunted by Shakespeare's archaisms, in Germany, through the translator's art, he bestrides the stage a colossus with a language as sharp, breezy, poetic, and idiomatic as it must have sounded at the Globe all those centuries ago.

All of this issue's contributors, in their own way, address the questions of the power of language in performance and its connection to both meaning and emotion.

Mina Kyounghye Kwon presents an excerpt of her translation of the Korean rod-puppet play kkokdugaksi noreum. Of all of the rich puppetry traditions of Asia, the Japanese bunraku and the Indonesian wayang kulit may be somewhat familiar to Western readers, but the Korean genres are much less well known. Kwon's translation introduces us to the garrulous folk character Bak Cheomji, whose boastful exploits animate the play, and provides a unique window into this popular tradition.

Following, reprinted here as a tribute to the issue's theme, are selected passages from German Enlightenment thinker and dramatist Gotthold Ephraim Lessing's Hamburg Dramaturgy in which Lessing specifically reflects upon the question of dramatic translation. At the time, German theatre was trying to find an autonomous voice and identity between English looseness and strict French neoclassicism. In Caron Cadle's translation, Lessing's keen understanding of dramatic form and his sparkling wit emerge intact.

My own renderings of four of Frank Wedekind's cabaret songs give a taste of this literary free spirit whose personal exploits as much as his daring texts scandalized the audiences of his time. One must imagine Wedekind's hulking figure strumming his guitar and singing these bawdy songs in a voice his admirer Bertolt Brecht described as "creaky, somewhat monotone, and very untrained."

Brecht himself is at issue in Peter Ferran's essay on the most familiar ballad to emerge from his international smash hit The Threepenny Opera (1928), the song of "Mackie Messer," or Mac the Knife. The ubiquitous translation of this iconic song by Marc Blitzstein — popularized by Louis Armstrong and others - rings in our ears, but Ferran's careful excavation of Brecht's gestus (what we might call the performative iteration of his social attitude) reveals how slyly the ditty implicates its audience in the lionization of crime. 
The current Broadway remount of the iconic musical West Side Story under the direction of Ivo van Hove and the forthcoming Steven Spielbergdirected film make Colleen Rua's exploration of the politics of bilinguality in this piece particularly urgent. Part of her larger work on Latinx representation on Broadway, the essay reads the ambivalent response to the "codeswitching" of lyrics in a recent revival as characteristic of the still-problematic effort to bring Latinidad to the mainstream stage.

The obverse holds for the case of David Bowie's musical Lazarus, which Susan Ingram discusses in her contribution. German audiences in particular embraced the production precisely because it maintained a balance between translated dialogue and the original English lyrics. It was the translator's decision to leave Bowie's songs in their original language that allowed them to unfold their greatest affective power and resonance.

The Sicilian playwright Emma Dante is the subject of Francesca Spedalieri's essay and her translation of an excerpt of the play mPalermu. Spedalieri traces how the interweaving of Palermitan dialect and standard Italian recapitulates the characters' ambiguous position between their regional identity and their longing to join the cultural and linguistic mainstream of a country that relegates them to near-colonial status. Spedalieri's "foreignized" translation makes this contradiction audible, palpable to English-speaking audiences.

Brazilian performer Beatriz Azevedo's "ground-floor-poem" Peripatetic occupies the space between spoken-word poetry and performance art. In Charles Perrone's skillful translation the poem resonates with the pulse of urban life as the text of the city and the architecture of the words coalesce.

The issue is rounded out by an expansive review essay by Stephen Rojcewicz of two novels by Olga Tokarczuk and their translations. Tokarczuk received the 2018 Man Booker Prize and the 2018 Nobel Prize for Literature, making the essay particularly timely. Tokarczuk's writing is rich with linguistic layers and shifting points of view, and Rojcewicz manages deftly to elucidate her dense textual and thematic world. 